\title{
Attitude Toward Social Enterprises: A Comparison between For-Profit and Social Enterprise Employees
}

\author{
Eunsoo Choi ${ }^{1}{ }^{1 * \mathbb{C}}$, Eunji Kim ${ }^{1}$, Inji Kim ${ }^{2}$ and Incheol Choi ${ }^{3, *}$ \\ 1 Department of Psychology, Korea University, Seoul 02841, Korea; joanej@korea.ac.kr \\ 2 Pluscope, Seoul 10881, Korea; kim.inji@gmail.com \\ 3 Department of Psychology, Seoul National University, Seoul 08826, Korea \\ * Correspondence: taysoo@korea.ac.kr (E.C.); ichoi@snu.ac.kr (I.C.)
}

Received: 4 March 2020; Accepted: 28 March 2020; Published: 30 March 2020

\begin{abstract}
Social enterprises, organizations that pursue social purposes while generating profits, have garnered attention recently as potential key players for a sustainable economy. However, research on the perception of social enterprises by lay people has been ignored even though positive reception of social enterprises is an important condition for their sustainability. In the present study, we compared for-profit enterprise employees $(n=200)$ and social enterprise employees $(n=162)$ and examined their differences in attitude toward the profit-making aspects of social enterprises as well as the employees working for social enterprises. The results showed that for-profit enterprises overestimated that social enterprise employees were extrinsically motivated and underestimated their prosocial intentions. In addition, for-profit enterprise employees were less favorable toward the profit-making aspects of social enterprises, including payment of high salaries for the social enterprise employees and using donations to run social enterprises. Interestingly, the difference between for-profit and social enterprise employees in their attitude toward the profit-making aspects of social enterprises was explained by lay theories of altruism called "pure altruism." The present research makes important contributions by identifying the psychological mechanisms that underlie individuals' perceptions and attitude toward social enterprises.
\end{abstract}

Keywords: social enterprise; lay theory; altruism; prosocial motivation; extrinsic motivation; profit-making

\section{Introduction}

A social enterprise is a novel type of enterprise with a relatively short history [1]. Western Europe, particularly England, was among the first to publicly recognize the concept of social enterprise in the early 1990s. This new form of organization executes business activities, including the production and sales of goods and services, while pursuing social purposes [2]. In other words, social enterprises focus on the traditional goal of a general enterprise, which is to make profits and increase market share, but also address social problems and deliver public services [3-5]. As such, social enterprises are organizations that seek both financial and social value [6,7].

Although there has been institutional support from governments and policy makers to promote social enterprises, confusion around the concept abounds. Academics and practitioners have disagreements about what attributes organizations must possess to qualify as social enterprises [8]. Different conceptualizations of social enterprises throughout the world add to the confusion [9]. More importantly, the nature of a social enterprise deviating from the existing organizations, which are either for-profit or nonprofit, seems to make lay people resistant to this novel type of organization [10]. There is in fact "misunderstanding" of the nature of social enterprises among the general population, which makes it important to unravel the reasons for such misunderstanding. 
Daniel Pallotta's case provides an illustrative example of such resistance [11]. Daniel Pallotta ran a company called Pallotta TeamWorks which successfully raised funds for nonprofit charities for causes like AIDS and cancer research. However, Pallotta TeamWorks itself was a for-profit organization and Pallotta earned around $\$ 400,000$ as the company's chief executive officer. When this became public knowledge, Pallotta TeamWorks was heavily criticized by the public and charities stopped hiring the company, which eventually resulted in its shutdown. Unfortunately, due to the collapse of Pallotta's company, the charities served by Pallotta TeamWorks also saw a sharp decrease in donations. The public response for Pallotta's case reflects that lay people perceive that a company's financial profits and social values are incompatible, which is referred to as "anti-profit belief" by some researchers [12]. People are also quite sensitive to the potential gains that individual donors of volunteers might acquire from their charitable acts [13-15]. Prior research has documented that people are particularly critical when they believe that good deeds, including charitable works, are motivated by self-interest.

Given this background, the present study examines the general perception of social enterprises, with a specific focus on how lay people interpret the dual nature-selfish (profit-seeking) and selfless (socially responsible) — of social enterprises. A comparison of lay people's attitudes toward social enterprises with a group of individuals who are well-versed with social enterprises would shed light on the underlying mechanisms for this misperception. Thus, in this study, we will investigate the lay perception of social enterprises in South Korea, which only recently began to see the emergence of social enterprises under a government-led initiative [16]. Although a recent survey suggests that the Korean public became more familiar with social enterprises than when they were first introduced by the government, it is yet to be explored what specific attitudes people have toward social enterprises. [17]. Considering that social enterprises can potentially solve social problems that other organizations have failed to solve [18], it is important to understand the specific psychological mechanisms that underlie people's perception of this newly constructed organization.

\subsection{Lay Theories about Altruism and Perception of Social Enterprises}

One common perception that lay people have regarding social enterprises which may contribute to their negative evaluations is that social enterprises are not as altruistic as they should be. In general, people believe that others are motivated by self-interest [19]. For instance, people think that rewards such as monetary incentives will make people more involved in prosocial behavior. Moreover, people display "attributional cynicism" regarding selfless behaviors; that is, people are often reluctant to infer selfless motivations in others' good deeds even when there is evidence pointing that they are indeed selfless [12,20]. Given individuals' general perception when observing altruistic behaviors, it is reasonable to expect that people may infer self-interested motivations from social enterprises' activities. Because self-interest is associated with extrinsic rather than intrinsic rewards [21,22], one would think that individuals who work for social enterprise are extrinsically motivated to the extent that they are perceived to be self-interested. Therefore, when compared to social enterprise employees whom we utilized as a meaningful counterpart of the general public, individuals would perceive that social enterprise employees would be motivated by extrinsic rewards.

Moreover, individuals would have cynical views regarding the profit-making aspects of social enterprises. To provide the public services and gain social values, social enterprises have the inherent goal of reinvesting surplus to a business through their activities [18,23]. In fact, market revenues are essential for organizational sustainability [24]. However, as seen in Pallotta's case, one of the challenges social enterprises or corporate social responsibility (CSR) activities face is consumers' skepticism of or resistance to the profits these organizations make while pursuing social value [25-27]. This may be because people generally hold beliefs that profit-seeking is inevitably associated with harmful outcomes for the collective [12,28]. However, social enterprise employees, the comparison group of the present study, either because of greater knowledge of social enterprises or of self-serving bias [29], show greater acceptance for profit-making of social enterprise. Thus, one would expect that such 
individuals in general would disapprove of the profit-making aspects of social enterprises, such as excessive salary paid to the employees.

One potential psychological condition that may account for the tendency to undermine charitable acts is when people think that selfish motivation cannot coexist with other-oriented motivations. The two seemingly "contradictory" goals of pursuing social purposes and economic profits are by no means the same goals; however, they are not necessarily conflicting with one another, either [30]. However, for "pure altruists," who believe that altruistic behaviors should only be motivated by purely selfless motivations [31], a social enterprise is likely to be considered as a "for-profit enterprise in disguise" [16]. In the present study, we propose that social enterprises would be perceived differently depending on the lay theories of altruism. Specifically, for people who endorse pure altruism, profits made by social enterprises would signal that their activities may not be as altruistic as they seem and therefore not as desirable. That is, we predicted that beliefs in pure altruism would indicate negative perceptions of the profit-making aspects of social enterprises.

\subsection{Study Overview}

Social enterprises are different from conventional organizations, which are either for-profit or nonprofit. In particular, the profit-seeking aspects of a social enterprise make individuals skeptical about its prosocial purpose. In this study, we examine two groups that are presumed to vary in their familiarity with social enterprises-employees working for for-profit companies and employees working for social enterprises. By comparing these two groups, we aim to show that the general population (employees in for-profit enterprises) is more skeptical of the intentions of social enterprises than employees working for the same companies. We predict that employees in for-profit enterprises would attribute more extrinsic (i.e., self-interested) motivations (e.g., financial incentives, social reputation) and less prosocial (i.e., other-oriented) motivations (e.g., finding meaning and purpose, making a social contribution) than those reported by social enterprise employees.

Relatedly, for-profit company employees are predicted to be more skeptical about the profit-making aspects of social enterprises and would therefore disapprove of utilizing profits to operate social enterprises. The current research assesses the degree to which they approve of paying high salaries for social enterprise employees and the use of donations for operating social enterprises. Finally, in the present research, the perceptions of social enterprises are posited to be influenced by one's beliefs about altruism. Specifically, we hypothesize that those who believe that helping is altruistic only when the underlying motivations are selfless would be more cynical and unfavorable to social enterprises. In other words, we expect that the difference between for-profit and social enterprise employees would be explained by one's beliefs about pure altruism.

Hypothesis 1. For-profit employees will view social enterprise employees as more extrinsically motivated and less prosocially motivated than social enterprise employees themselves report.

Hypothesis 2. For-profit employees will be less likely to approve of paying high salaries to social enterprise employees and using donated money to reinvest in social enterprises.

Hypothesis 3. The differences between for-profit and social enterprise employees in their evaluations of social enterprise will be mediated by lay theories about pure altruism.

\section{Materials and Methods}

\subsection{Participants}

The participants were 162 employees $\left(M_{\mathrm{age}}=31.78, S D_{\mathrm{age}}=6.33 ; 41\right.$ males, 114 females $)$ working for social enterprises and 200 employees $\left(M_{\text {age }}=39.42, S D_{\text {age }}=8.03,100\right.$ males, 100 females $)$ working for for-profit enterprises (7 participants in the social enterprise employee group did not report their age). 
Social enterprise employees were recruited through online bulletin board and snowball sampling was done via e-mail. For-profit company employees were recruited via a research company in South Korea. To the best of our knowledge, since the present research was the first to directly compare social enterprise and for-profit employees, a sensitivity analysis was conducted to determine whether the sample size was adequate. We conducted power analysis using $G^{*}$ Power, which indicated that for ANCOVA with two groups, this sample size provided $80 \%$ power at $\alpha=0.05$ to detect a small-to-medium effect size (Cohen's $f^{2}=0.15$ ). The study protocol was approved by the Institutional Review Board at Seoul National University (1707/001-011).

\subsection{Measures}

\subsubsection{Prosocial vs. Extrinsic Motivations of Social Enterprise Employees}

We asked participants about their motivations for working for a social enterprise. Social enterprise employees responded regarding their own motivations, while for-profit enterprise employees inferred their thoughts regarding the motivations of social enterprise employees. Eight items assessed different motivations behind working for social enterprises (e.g., "I am working for a social enterprise because I want to bring change to a society"; "I am working for a social enterprise for the money"). Principle component analysis (PCA) with varimax rotation yielded two factors. Five items loaded on the first factor representing prosocial motivation (loadings $>0.50$ ), which accounted for $35.58 \%$ of the variances (e.g., "I am working for a social enterprise to help underprivileged people"). The other three items loaded on the second factor addressing extrinsic motivation (all loadings above 0.73 ) and accounted for the additional $23.63 \%$ of the variance (e.g., "I am working for a social enterprise for the recognition I would get from people"). Reliability analyses indicated adequate internal consistency for both prosocial and extrinsic motivation: Cronbach's $\alpha$ is 0.79 and 0.66 , respectively. Prosocial and extrinsic motivations were independent from one another: $r=0.04$ and $p=0.479$.

\subsubsection{Attitude toward the Profit-Making Aspects of Social Enterprises}

As for the attitude toward the profit-making aspects of social enterprises, four items were assessed to measure attitude toward high salaries for social enterprise employees and the use of donations in operating social enterprises. As we intended, two factors emerged from PCA with varimax rotation, jointly accounting for $83.0 \%$ of the variance. The two items addressing attitude toward high salary payments for social enterprise employees (loadings $>0.84$ ) loaded on the first factor, which explained $45.4 \%$ of the variance (e.g., "It is not desirable to pay high salaries to social enterprise employees," reverse-coded). The two items on using donations to operate social enterprises loaded on the second factor (loadings $>0.93$ ), which explained $37.6 \%$ of variance (e.g., "It is appropriate to use donated funds for the operational expenses of social enterprise"). These four items were averaged to create an index of attitude toward the profit-making aspects of social enterprises (Cronbach's $\alpha=0.72$ ). Despite their brevity, two-item factors have been used in previous studies (e.g., Big 5) and demonstrated good psychometric properties [32,33].

\subsubsection{Pure Altruism}

Pure altruism focused on individual differences in the degree to which one allows for self-oriented motivations in prosocial behaviors [34]. Pure altruism measures how much one endorses the argument that for a prosocial act to be altruistic, there should not be any self-interested motivations. This construct included five self-interested motivations that past research has identified in altruistic behavior $[18,19]$ : (1) Earning a positive reputation, (2) feeling good about oneself, (3) avoiding feeling guilty for not helping, (4) gaining actual benefits (e.g., return of favor or tax benefits, learning experience, or business contacts), and (5) fulfilling one's duty as members of a society. First, participants were provided with the following instruction: "There are different motivations behind helping others. Helping can be interpreted in many ways, depending on what people think about the underlying motivations." Next, 
participants were asked how much they agreed with each of the five statements. Their responses included: "Helping others to build a positive reputation cannot be considered altruistic"; "Helping others to gain actual benefits (e.g., return of favor or tax benefits, learning experience, or business contacts) is not altruistic." Responses were made on a 7-point scale, ranging from $1=$ strongly disagree to $7=$ strongly agree. In an exploratory PCA with varimax rotation, the five items loaded on one factor, explaining 59.3\% of the variance. The measurement had good internal reliability, with Cronbach's $\alpha$ of 0.83. A higher score indicated lower acceptance of self-interested motivations in altruism.

\subsubsection{Control Variables}

We controlled for age, gender, and educational level $(1=$ less than middle school, $2=$ middle school, $3=$ high school, $4=$ college, $5=$ university, $6=$ graduate school, $7=$ doctoral) of the participants. However, dropping any control variable from the analyses did not change the results reported below.

\section{Results}

There were differences between social enterprise employees and for-profit enterprise employees in gender ratio, age, and educational level. There was a higher proportion of women in the social enterprise employees (73.5\%) than in the for-profit enterprise employees $(50.0 \%), \chi^{2}(355)=20.23$, $p<0.001$. The mean age of for-profit enterprise employees was higher than for social enterprise employees: $t(351.79)=10.00, p<0.001$. As for the educational level, social enterprise employees had higher levels of education compared to for-profit employees: $F(351.79)=50.58, p<0.001$. Age, gender, and educational level were controlled for in the subsequent analyses.

\subsection{Prosocial vs. External Motivations}

First, we tested whether the perception of motivations of social enterprise employees are interpreted differently by employee and motivation types. As responses for prosocial and extrinsic motivations were correlated with each other, we conducted a $2 \times 2$ mixed model ANOVA (employee type: social enterprise employees vs. for-profit company employees; motivation type: prosocial vs. extrinsic), while controlling for age, gender, and educational level. There was a significant main effect of employee type $\left(F(1348)=7.55, p=0.001, \eta_{\mathrm{p}}{ }^{2}=0.031\right)$ and a marginally significant effect of motivation type $\left(F(1348)=3.37, p=0.067, \eta_{\mathrm{p}}^{2}=0.010\right)$. However, this was qualified by a significant interaction between employee type and motivation type: $F(1348)=57.38, p<0.001, \eta_{\mathrm{p}}{ }^{2}=0.142$. Follow-up contrasts showed that social enterprise employees reported greater prosocial motivation $(M=4.77, S E M=0.10)$ than for-profit enterprise employees estimated $(M=4.42, S E M=0.09): F(1348)=5.91, p=0.016$, $\eta_{\mathrm{p}}{ }^{2}=0.017$. In contrast, social enterprise employees reported lower levels of extrinsic motivation $(M=2.74, S E M=0.10)$ than what for-profit enterprise employees had estimated $(M=3.81, S E M=0.08)$ : $F(1,348)=56.65, p<0.001, \eta_{\mathrm{p}}{ }^{2}=0.140$ (Figure 1). The finding suggests that for-profit employees believed employees of social enterprise to have higher levels of extrinsic motivation and lower levels of prosocial motivation than social enterprise employees themselves reported to have. Thus, Hypothesis 1 was supported.

\subsection{Attitude toward the Profit-Making Aspects of Social Enterprises}

We found that there was a significant difference in the attitude toward the profit-making aspects of social enterprises between the two different types of employees while controlling for covariates: $F(1353)=66.14, p<0.001, \eta_{\mathrm{p}}{ }^{2}=0.159$. Specifically, social enterprise employees approved of paying high salaries to social enterprise employees $\left(F(1353)=50.03, p<0.001, \eta_{\mathrm{p}}{ }^{2}=0.125\right)$ and using donations to run social enterprises to a greater degree than for-profit company employees $(F(1,353)=74.69$, $p<0.001, \eta_{p}^{2}=0.159$ ). This supports Hypothesis 2 (Table 1 ). 


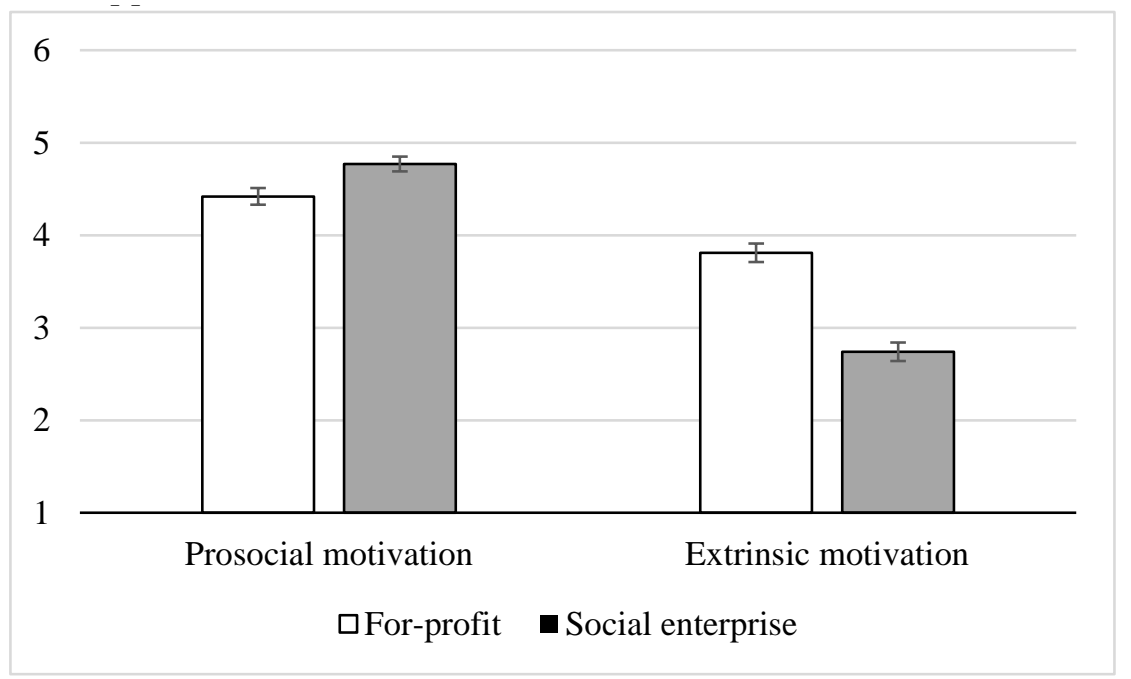

Figure 1. Prosocial and extrinsic motivation of social enterprise employees by employee type (for-profit vs. social enterprise).

Table 1. Descriptive statistics and intercorrelations among study variables.

\begin{tabular}{lccccccccc}
\hline & $\begin{array}{c}\text { Social } \\
\text { Enterprise }\end{array}$ & $\begin{array}{c}\text { For-Profit } \\
\text { Enterprise }\end{array}$ & & & & & \\
& \multicolumn{1}{c}{$\mathbf{M}(\mathbf{S D})$} & $\mathbf{M}(\mathrm{SD})$ & $\mathbf{1}$ & $\mathbf{2}$ & $\mathbf{3}$ & $\mathbf{4}$ & $\mathbf{5}$ & $\mathbf{6}$ \\
\hline 1. Prosocial motivation & $4.88(1.33)$ & $4.33(0.93)$ & - & 0.07 & $0.22^{* *}$ & $0.48^{* *}$ & $0.43^{* *}$ & $-0.18^{* *}$ \\
2. Extrinsic motivation & $2.81(1.25)$ & $3.76(0.97)$ & $0.25^{* *}$ & - & -0.09 & -0.04 & -0.08 & -0.05 \\
3. Profit-making: salary & $5.44(1.43)$ & $4.05(1.18)$ & 0.01 & -0.07 & - & $0.35^{* *}$ & $0.80^{* *}$ & $-0.20^{*}$ \\
4. Profit-making: donation & $5.15(1.60)$ & $3.98(1.42)$ & $0.35^{* *}$ & 0.05 & -0.01 & - & $0.84^{* *}$ & $-0.28^{* *}$ \\
5. Profit-making: total & $5.29(1.24)$ & $4.01(0.92)$ & $0.28^{* *}$ & -0.01 & $0.64^{* *}$ & $0.77^{* *}$ & - & $-0.29^{* *}$ \\
6. Pure altruism & $3.08(1.18)$ & $3.69(1.05)$ & $-0.17^{*}$ & 0.13 & -0.13 & $-0.16^{*}$ & $-0.21^{* *}$ & - \\
\hline
\end{tabular}

Note. Intercorrelations for social enterprises are presented above the diagonal, while intercorrelations for for-profit enterprise employees are presented below it. ${ }^{*} p<0.05,{ }^{* *} p<0.01$.

\subsection{Pure Altruism}

We obtained a significant effect of employee type on pure altruism: $F(1349)=10.47, p=0.001$, $\eta_{\mathrm{p}}{ }^{2}=0.029$. Specifically, for-profit enterprise employees $(M=3.69, S D=1.05)$ reported higher levels of pure altruism than social enterprise employees $(M=3.04, S D=1.17)$.

\subsection{Mediation Analyses}

To test Hypothesis 3, we conducted mediational analyses examining whether pure altruism mediated the difference in two indices of attitude toward the profit-making aspects of social enterprises between for-profit and social enterprise employees. Unlike the Sobel test, as bootstrapping is free of a priori assumption of the sampling distribution [35], we conducted our mediational analysis with a PROCESS macro [36] with 5000 bootstrap resampling and a $95 \%$ confidence interval (CI). If 0 was not included in the interval, the indirect effect was significant, and pure altruism mediated the link between employee type and attitude. Consistent with Hypothesis 3, the indirect effect was significant for the overall profit-making aspects of social enterprises: $b=0.11, S E=0.04,95 \% \mathrm{CI}=0.03-0.20$. Moreover, the indirect effect was significant for both attitudes regarding salaries for social enterprise employees $(b=0.08, S E=0.04,95 \% \mathrm{CI}=0.01-0.17)$ and attitudes regarding the use of donations $(b=0.11, S E=0.04,95 \% C I=0.03-0.20)$. Table 2 presents the full results of the mediational analysis. 
Table 2. Mediation effect of pure altruism on the association between employee type (for-profit vs. social enterprise) and attitude toward the profit-making aspects of social enterprises.

\begin{tabular}{|c|c|c|c|c|c|c|}
\hline Perception of SE (Y) & $\begin{array}{c}\text { Employee } \\
\text { Type (X) } \\
\text { Predicting } \\
\text { PA(M) } \\
\text { (a-path) }\end{array}$ & $\begin{array}{c}\text { PA (M) } \\
\text { Predicting } \\
\text { Attitude (Y) } \\
\text { (b-path) }\end{array}$ & $\begin{array}{c}\text { Total } \\
\text { Effect } \\
\text { (c-path) }\end{array}$ & $\begin{array}{c}\text { Direct } \\
\text { Effect } \\
\text { (c' path) }\end{array}$ & $\begin{array}{c}\text { Indirect } \\
\text { Effect }\end{array}$ & $95 \% \mathrm{CI}$ \\
\hline Profit-making: salary & $-0.46^{* *}$ & $-0.17 *$ & $1.16^{* *}$ & $1.08^{* *}$ & $0.08(0.04)$ & $0.01-0.17$ \\
\hline Profit-making: donation & $-0.46^{* *}$ & $-0.23^{* *}$ & $1.23^{* *}$ & $1.02 * *$ & $0.11(0.03)$ & $0.03-0.20$ \\
\hline Profit-making: total & $-0.46^{* *}$ & $-0.23 * *$ & $1.13^{* *}$ & $1.02 * *$ & $0.11(0.03)$ & $0.03-0.20$ \\
\hline
\end{tabular}

Note. $\mathrm{SE}=$ social enterprise; $\mathrm{PA}=$ pure altruism; ${ }^{*} p<0.01,{ }^{* *} p<0.001$.

\section{Discussion}

The present study examined how individuals perceive social enterprises by comparing employees from two different types of organizations: for-profit and social enterprises. As social enterprise employees are much more familiar with social enterprises and, therefore, are relatively less subject to the "misperception" of social enterprises, we believed that the social enterprise employees group would be a meaningful comparison group to the for-profit enterprise employees group that is more representative of the general population.

This research has found the following. First, the two groups significantly differed in their perceptions of employees working for social enterprises. Specifically, for-profit enterprise employees overestimated the degree to which social enterprise employees were extrinsically motivated but underestimated their prosocial motivations. This was consistent with prior research showing that people generally consider seemingly altruistic behaviors as self-interested $[15,20]$. Considering that prosocial corporate activities such as CSR backfire when people believe that the motivations of the companies are insincere [26], overestimating self-interested motivations of social enterprise employees would hinder the success of social enterprises [37].

Second, for-profit enterprise employees were more skeptical about the profit-making aspects of social enterprises. Although making a profit is an important goal for social enterprises to achieve to make the organization sustainable [38], the findings from the present study suggest that compared to social enterprise employees, individuals working for for-profit enterprises did not approve of the idea of paying high salaries to social enterprise employees. Moreover, while donations are essential resources with which social enterprises operate [39], for-profit enterprise employees were much more reluctant to agree that donations can be used as expenses for managing social enterprises. These results directly show the discrepancy between for-profit employees and social enterprise employees in their overall attitude toward social enterprises, and attest to the obstacles that this hybrid organization faces [2].

Third, one crucial psychological mechanism that explains the discrepancies between the two groups related to individuals' theories about self-interested motivations in charitable acts. We know from previous research that there are individual differences in one's theories about pure altruism, a belief that altruistic behaviors should be motivated by selfless motivations only [34]. It turned out that for-profit enterprise employees had stricter standards for the motivations of altruistic behaviors than social enterprise employees. Naturally, for-profit enterprise employees perceived social enterprises, driven by a combination of two distinct goals of pursuing profits and social values, as "impure." Furthermore, the individual differences in pure altruism indeed explained the difference between for-profit and social enterprise employees in their attitude toward the profit-making aspects of social enterprises. The findings of the present research suggest that one potential strategy with which attitudes to social enterprises can be shaped is by intervening with lay theories about altruism. For example, changing one's lay theories has far-reaching effects on one's attitudes and behaviors [40]. 
There has been an effort to understand social enterprises from the perspective of business, policy administration, or social work, focusing on the impact of policy on performance [41] or on the characteristics of social entrepreneurs [42]. However, few studies have examined how lay people, the potential consumers, perceive and evaluate social enterprises and their employees (for an exception, see [43]). The present study thus provides a powerful demonstration of how the general population has been "misunderstanding" the nature of social enterprises by contrasting them with a group of people who are currently working for social enterprises. Furthermore, considering that positive perception is a prerequisite for social enterprises to sustain and expand their activities, the present research makes important contributions by identifying the psychological mechanisms that underlie individuals' perceptions and attitudes toward social enterprises. Thus, the findings from the present research imply that to generate a more positive perception of social enterprises in a general population, it is important for social enterprises to promote their socially responsible values while persuading the public of the compatibility or necessity of the profit-making aspects of the social enterprise.

\section{Limitations and Future Research}

Despite the contributions of the present research, there are some limitations to be addressed. Although we posited pure altruism as a mediating factor, the causal relationship between employee type and pure altruism cannot be established. That is, whether social enterprise employees became more accepting of "impure altruism" by working at their organizations or those who endorse impure altruism were selected to work for social enterprises is unclear. Future research with longitudinal design is needed to test this causal link. In addition, although the social enterprise employees group served as a meaningful counterpart that effectively represented lay people's attitude toward social enterprises, their self-reports on their motivations for working for social enterprises are likely to be subject to a social desirability bias. More diverse measures assessing the motivations and attitudes of social enterprise employees may be worthwhile. Moreover, another limitation of the study was that the two groups, social enterprise and for-profit employees, differed in demographic characteristics including gender ratio, age, and educational level. However, the exclusion of control variables did not change the results. Finally, the current study was conducted in South Korea, where the public awareness of social enterprises is especially low despite a thirtyfold increase in the number of social enterprises in the past decade thanks to the institutional support from the government [44]. Thus, the current findings should be interpreted while taking cultural context into account.

Author Contributions: E.C., I.K., and I.C. developed the study design; I.K. collected and analyzed the data; E.K. and E.C. reviewed the literature and authored the article; I.C. reviewed the article; E.C. and I.C. acquired funding. All authors have read and agreed to the published version of the manuscript.

Funding: This research has been supported by the Center for Social Value Enhancement Studies and the Happiness Foundation.

Conflicts of Interest: The authors declare no conflict of interest.

\section{References}

1. Parry, S. Smalltalk: Rhetoric of control as a barrier to growth in artisan micro-firms. Int. Small Bus. J. 2010, 28, 378-397. [CrossRef]

2. Chung, S.H.; Cho, S.M. The effect of hybrid factor on the performance of social enterprise: Focusing on mediating effect of social entrepreneurship. Soc. Enterp. Stud. 2018, 11, 125-162.

3. Defourny, J.; Nyssens, M. Conceptions of social enterprise and social entrepreneurship in Europe and the United States: Convergences and divergences. J. Soc. Entrep. 2010, 1, 32-53. [CrossRef]

4. Wiklund, J.; Davidsson, P.; Delmar, F. What do they think and feel about growth? An Expectancy-value approach to small business managers' attitudes towards growth. Entrep. Theory Pract. 2003, 27, 247-269. [CrossRef]

5. Doern, R. Investigating barriers to SME growth and development in transition environments: A critique and suggestions for developing the methodology. Int. Small Bus. J. 2009, 27, 275-305. [CrossRef] 
6. Costanzo, L.A.; Vurro, C.; Foster, D.; Servato, F.; Perrini, F. Dual-Mission Management in Social Entrepreneurship: Qualitative Evidence from Social Firms in the United Kingdom. J. Small Bus. Manag. 2014, 52, 655-677. [CrossRef]

7. Besley, T.; Ghatak, M. Profit with purpose? A theory of social enterprise. Am. Econ. J. Econ. Policy 2017, 9, 19-58. [CrossRef]

8. Lyon, F.; Teasdale, S.; Robyn, O. Approaches to Measuring the Scale of the Social Enterprise Sector in the UK; Lyon, F., Teasdale, S., Baldock, R., Eds.; Third Sector Research Centre, University of Birmingham: Birmingham, UK, 2010.

9. Kerlin, J.A. A comparative analysis of the global emergence of social enterprise. Volunt. Int. J. Volunt. Nonprofit Organ. 2010, 21, 162-179. [CrossRef]

10. Cho, E.M.; Lee, E.S. The effects of corporate social responsibility activities, social enterprise attitude, and reliability in the products of social enterprise on the purchase intention: Perspective of social enterpriser. J. CEO Manag. Stud. 2015, 18, 69-98.

11. Kristof, N.D. The sin in doing good deeds. New York Times. Available online: http//www.nytimes.com/2008/ 12/25/opinion/25kristof.html (accessed on 28 January 2020).

12. Bhattacharjee, A.; Dana, J.; Baron, J. Anti-profit beliefs: How people neglect the societal benefits of profit. J. Pers. Soc. Psychol. 2017, 113, 671-696. [CrossRef]

13. Carlson, R.W.; Zaki, J. Good deeds gone bad: Lay theories of altruism and selfishness. J. Exp. Soc. Psychol. 2018, 75, 36-40. [CrossRef]

14. Lin-Healy, F.; Small, D.A. Cheapened altruism: Discounting personally affected prosocial actors. Organ. Behav. Hum. Decis. Process. 2012, 117, 269-274. [CrossRef]

15. Newman, G.E.; Cain, D.M. Tainted Altruism: When Doing Some Good Is Evaluated as Worse Than Doing No Good at All. Psychol. Sci. 2014, 25, 648-655. [CrossRef] [PubMed]

16. Kim, H.S. Analysing the sustainability of social enterprises in the community. Korean J. Local. Gov. Stud. 2012, 16, 259-277.

17. Lee, H.J.; Lee, S.W. A study on the perception of social enterprise: Using Naver trends data. Soc. Enterp. Stud. 2018, 11, 51-74.

18. Teasdale, S. What's in a Name? Making Sense of Social Enterprise Discourses. Public Policy Adm. 2012, 27, 99-119. [CrossRef]

19. Ratner, R.K.; Miller, D.T. The norm of self-interest and its effects on social action. J. Pers. Soc. Psychol. 2001, 81, 5-16. [CrossRef]

20. Critcher, C.R.; Dunning, D. No good deed goes unquestioned: Cynical reconstruals maintain belief in the power of self-interest. J. Exp. Soc. Psychol. 2011, 47, 1207-1213. [CrossRef]

21. Frisch, M.; Frisch, M. The human face of causation. Causal Reason. Phys. 2014, 48-76.

22. MacIntyre, A. After Virtue: A Study in Moral Theory; Bloomsbury Academic: London, UK, 2007.

23. Dey, P.; Teasdale, S. Social Enterprise and Dis/identification. Adm. Theory Prax. 2013, 35, 248-270. [CrossRef]

24. Moizer, J.; Tracey, P. Strategy making in social enterprise: The role of resource allocation and its effects on organizational sustainability. Syst. Res. Behav. Sci. 2010, 27, 252-266. [CrossRef]

25. Skarmeas, D.; Leonidou, C.N. When consumers doubt, Watch out! The role of CSR skepticism. J. Bus. Res. 2013, 66, 1831-1838. [CrossRef]

26. Yoon, Y.; Gurhan-Canli, Z.; Schwarz, N. The effect of corporate social responsibility ( CSR ) activities on companies with bad reputations. J. Consum. Psychol. 2006, 16, 377-390. [CrossRef]

27. Vaidyanathan, R.; Aggarwal, P. Using commitments to drive consistency: Enhancing the effectiveness of cause-related marketing communications. J. Mark. Commun. 2005, 11, 231-246. [CrossRef]

28. Inbar, Y.; Pizarro, D.A.; Cushman, F. Benefiting from misfortune: When harmless actions are judged to be morally blameworthy. Personal. Soc. Psychol. Bull. 2012, 38, 52-62. [CrossRef]

29. Zuckerman, M. Attribution of success and failure revisited, or: The motivational bias is alive and well in attribution theory. J. Pers. 1979, 47, 245-287. [CrossRef]

30. Song, S.Y.; Kim, Y.K. Doing good better: Impure altruism in green apparel advertising. Sustainability 2019, 11, 1. [CrossRef]

31. Sober, E.; Wilson, D.S. Unto Others: The Evolution and Psychology of Unselfish Behavior; Harvard University Press: Boston, MA, USA, 1999; ISBN 0674930479. 
32. Rammstedt, B.; John, O.P. Measuring personality in one minute or less: A 10-item short version of the Big Five Inventory in English and German. J. Res. Pers. 2007, 41, 203-212. [CrossRef]

33. Baumert, A.; Beierlein, C.; Schmitt, M.; Kemper, C.J.; Kovaleva, A.; Liebig, S.; Rammstedt, B. Measuring four perspectives of justice sensitivity with two items each. J. Pers. Assess. 2014, 96, 380-390. [CrossRef]

34. Choi, E.; Kim, I.; Choi, I. Against pure altruism: A case for impure view of altruism. 2019; Unpublished work.

35. Biesanz, J.C.; Falk, C.F.; Savalei, V. Assessing mediational models: Testing and interval estimation for indirect effects. Multivariate Behav. Res. 2010, 45, 661-701. [CrossRef]

36. Preacher, K.J.; Hayes, A.F. Asymptotic and resampling strategies for assessing and comparing indirect effects in multiple mediator models. Behav. Res. Methods 2008, 40, 879-891. [CrossRef] [PubMed]

37. Vanhamme, J.; Grobben, B. "Too good to be true!". The effectiveness of CSR history in countering negative publicity. J. Bus. Ethics 2009, 85, 273. [CrossRef]

38. Chung, D.Y.; Kim, M.S. The effects of pursuit of the organizational members social \& economical values on the development of social enterprise. J. Ind. Econ. Bus. 2010, 23, 2299-2321.

39. Sullivan Mort, G.; Weerawardena, J.; Carnegie, K. Social entrepreneurship: Towards conceptualisation. Int. J. Nonprofit Volunt. Sect. Mark. 2003, 8, 76-88. [CrossRef]

40. Yeager, D.S.; Johnson, R.; Spitzer, B.J.; Trzesniewski, K.H.; Powers, J.; Dweck, C.S. The far-reaching effects of believing people can change: Implicit theories of personality shape stress, health, and achievement during adolescence. J. Pers. Soc. Psychol. 2014, 106, 867-884. [CrossRef]

41. Lee, J.H.; Cho, S.M.; Kwon, S.I. A study on social enterprise research trends based on keyword network analysis: Based on the publication of Korean academic journals from 2000 to 2017. Soc. Enterp. Stud. 2018, 11, 183-236.

42. Kim, K.H.; Ban, J.H. An exploratory study on the concepts and types of social enterprise in Korea. Q. J. Labor. Policy 2006, 6, 31-54.

43. Kim, C.B.; Baek, N.Y. The impact of consumers associations with social enterprises on corporate attitude: Focused on the mediating effect of trust and the moderating effect of self-congruity. Soc. Enterp. Stud. 2018, 11, 3-50.

44. Son, Y.G. Legal system for social enterprise and its evaluation to creating local jobs. J. Hum. Soc. Sci. 21 2016, 7, 223-250.

(C) 2020 by the authors. Licensee MDPI, Basel, Switzerland. This article is an open access article distributed under the terms and conditions of the Creative Commons Attribution (CC BY) license (http://creativecommons.org/licenses/by/4.0/). 